\title{
REAL ESTATE INVESTMENT TRUSTS IN TURKEY: STRUCTURE, ANALYSIS, AND STRATEGY
}

\author{
DOI: 10.17261/Pressacademia.2017.508 \\ JBEF- V.6-ISS.2-2017(14)-p.191-199
}

\author{
Ali Hepsen ${ }^{1}$, Murat G. Berberoglu², Olgun Aydin ${ }^{3}$ \\ ${ }^{1}$ Istanbul University, School of Business, Istanbul, Turkey. alihepsen@yahoo.com \\ ${ }^{2}$ General Secretary at GYODER, Istanbul, Turkey. mberberoglu@gyoder.org.tr \\ ${ }^{3}$ Mimar Sinan University, I nstitute of Science, Department of Statistics, Istanbul, Turkey. olgunaydinn@gmail.com
}

To cite this document

Hepsen, A., M. G. Berberoglu and O. Aydin (2017). Real estate investment trusts in Turkey: structure, analysis, and strategy. Journal of Business, Economics and Finance (JBEF), V.6, Iss.2, p.191-199.

Permemant link to this document: http://doi.org/10.17261/Pressacademia.2017.508

Copyright: Published by PressAcademia and limited licenced re-use rights only.

\begin{abstract}
Purpose- Aim of this study is to make the determinations related to the problems mentioned in the REIT sector in Turkey, to offer a solution for this issue, and to ensure the classification in the sector by adhering to the financial data of the REITs

Methodology- Financial data set of the REITs was firstly standardized by using median instead of mean. Then, the scoring was performed according to defined coefficients. After that normality test of the obtained scores was performed, the area of each score under standard normal distribution curve was calculated and the scores were moved to the 0-100 range. Finally, scores were collected under 5 groups as "Very good, Good, Not Bad, Bad and Very Bad" by using k-means algorithm. Clustering were made on R Studio.

Findings-Our analyses conducted that REITs traded on the Istanbul Stock Exchange are divided into two subgroups depending on their financial data.

Conclusion- It will be important the REITs, in the sub-group especially in terms of the score distribution, to diversify their portfolio by extending their asset investments, to stabilize dividend payments and to take steps on institutionalization so that they are equivalent to REITs in the supergroup.
\end{abstract}

Keywords: Real estate investment trusts (REITs), Turkey, performance ranking, K-means algoritm, R studio

JEL Codes: G12, G23, G29

\section{INTRODUCTION}

Real estate industry in Turkey has been always the biggest supporter and locomotive of the country's economy by itself by providing employment and business volume to more than 250 sub-sectors and has enabled reducing both general and seasonal unemployment by creating a permanent and regular job opportunity for the lowest skilled labor force. Institutionalization of this sector, which undertakes such important functions, is a very important resource for establishing reliable, long term, and transparent company structures for the construction industry in Turkey which must live with a very important risk especially such as earthquake. The Real Estate Investment Trusts (REITs) which are not engaged in construction work in Turkey according to the capital market legislation, could provide works to construction companies, to control them, and to enable them to operate at a certain level owing to both strong, accountable management structure and power of carrying out the large-sized 
projects. The present time shows that now the capital globally can change hands and geography very easily. Real estate is a very important investment tool all over the world. The REIT legislation currently in force in more than 30 countries that attract investments and investors is a very important instrument for all investors who are intending to invest in this area (EPRA Global REIT Survey, 2016). On the other hand, low transaction volume on the stock market, no obligation for disclosure of the net asset value, insufficient investor relations, loss of trust experienced during public offering, unhealthy and insecure sectoral data, REITs with very different portfolio sizes and diversities, confusions on the regulation side, and current dividend policy can be listed as the main and crucial problems in the sector which cause REITs to be traded at a high discount rate compared to the net asset value. When detailing the problems mentioned towards the REIT structure in Turkey, the fact that REITs' transaction volume in the Istanbul Stock Exchange is low, comes up against the investors. On the other hand, the fact that the net asset value tables required to be announced quarterly according to the capital market legislation until 2011 were excluded from the scope of the mandatory explanation after the decision taken by the Capital Markets Board (CMB) and that the net asset value follow-up has been left to the initiative of analysts or direction of the companies causes exclusion from an important REIT indicator and makes the performance of companies harder to follow, thus causing question marks about transparency. In addition, REITs make profit distribution decisions within the rates determined by the general assemblies at the end of the year and cannot display a sustainable dividend policy from the point of investor. This situation has resulted in a situation that does not attract REIT investors in terms of dividend income especially in the last period. An important problem in the sectoral sense is deficiency of the investor relations departments of the REITs. Even though there are departments called as investor relations in the REITs, most of them do not have officers who are focused on this subject. Apart from these, the data concerning both construction and real estate sector are extremely inadequate, their continuity is problematic, and their reliability is debatable. In this context, it is getting harder to draw a general picture of the sector to the investor and this situation abolishes the possibility of comparing with different countries during reflection of the general situation of the sector. The aim of this study is to make the determinations related to the problems mentioned in the REIT sector in Turkey, to offer a solution for this issue, and to ensure the classification in the sector by adhering to the financial data of the REITs.

\section{STRUCTURE OF REITS IN TURKEY}

Despite the intense demand in the real estate sector, due to reasons such as rapid population growth by years, broken families, urbanization phenomenon, increasing household income levels and rapidly developing construction technology, the difficulties in financing have led to different quests in the sector and different perspectives to come up. At this point, the first applications of the REIT structure to bring the real estate sector and the finance sector together are seen in the United States of America and this structure has started to be established also in Turkey and the stocks have started to be traded in Istanbul Stock Exchange. In this direction, according to the Turkish Association of Real Estate Investment Companies, the first REIT in Turkey was established in 1995, and as of today, the total number of REITs is 31 (CMB Monthly Statistical Bulletin, 2016).REITs are capital market institutions that can operate to invest in real estates and real estate-based capital market instruments, real estate projects, real estate-based rights, and capital market instruments (Chiang, Y.H., et. al., 2008). The REITs collect resources, obtained from many investors, in a pool by going public and realize valuable and high-amount real estate investments. Thus, while individual investors are given a chance to share indirectly in large real estate investments they cannot make with their own savings, investment risk can be reduced by investing with a diversified portfolio logic and professional asset management function in different projects (Basse and Friedrich, 2009). In this way, REITs can create a real market through the sale of their stocks on the stock market for illiquid real estates by obtaining the opportunity to invest professionally in estate projects with institutional principles. However, it can be asserted that REITs whose stocks are traded on the stock market in a contradict way to the importance and expressions here are traded with discount at a considerable ratio (Titman and Warga, 1986). The following table (Table 1) summarizes the situation, for example, while non-consolidated total assets of the sector are 53 billion TL in the first quarter of 2016, the market value sum is only 23 billion TL. Over the years a similar situation has been observed.

Table 1: Real Estate Investment Trusts in Turkey

\begin{tabular}{|l|c|c|c|c|c|}
\hline Period & $\begin{array}{c}\text { Number } \\
\text { of Trusts }\end{array}$ & \multicolumn{2}{|c|}{ Total Market Value } & \multicolumn{2}{|c|}{ Total Assets } \\
\hline & & Million TRY & Million \$ & Million TRY & Million \$ \\
\hline $2011 / 12$ & 23 & 11,708 & 6,224 & 20,770 & 11,041 \\
\hline $2012 / 12$ & 25 & 15,782 & 8,857 & 24,087 & 13,518 \\
\hline $2013 / 12$ & 30 & 18,632 & 8,730 & 37,573 & 17,604 \\
\hline
\end{tabular}




\begin{tabular}{|l|l|l|l|l|l|}
\hline $2014 / 12$ & 31 & 21,981 & 9,462 & 42,059 & 18,105 \\
\hline $2015 / 12$ & 31 & 21,280 & 7,279 & 52,530 & 17,969 \\
\hline $2016 / 03$ & 31 & 23,531 & 8,315 & 53,090 & 18,760 \\
\hline
\end{tabular}

Source: CMB Monthly Statistical Bulletin, July 2016.

Table 2 shows, number of total REITS and their total market values in various countries. For instance, out of 28 EU Member States, 12 have a REIT regime. Those 12 countries represent $83 \%$ of the EU GDP.

Table 2: Total Market Values of the REITs in Various Countries

\begin{tabular}{|l|c|c|l|c|c|}
\hline & $\begin{array}{c}\text { Number of } \\
\text { Trusts }\end{array}$ & $\begin{array}{c}\text { Total } \\
\text { Market Value } \\
\text { (Million EUR) }\end{array}$ & Number of & $\begin{array}{c}\text { Total } \\
\text { Trusts }\end{array}$ & $\begin{array}{c}\text { Market Value } \\
\text { (Million EUR) }\end{array}$ \\
\hline USA & 220 & 986,770 & Spain & 5 & 7,806 \\
\hline Australia & 61 & 106,458 & Turkey & 31 & 7,131 \\
\hline Japan & 56 & 102,695 & Malaysia & 16 & 6,381 \\
\hline UK & 36 & 56,585 & N. Zealand & 6 & 3,973 \\
\hline Singapore & 44 & 51,236 & Germany & 4 & 2,792 \\
\hline France & 32 & 49,357 & Ireland & 3 & 2,416 \\
\hline Canada & 46 & 41,180 & Italy & 3 & 2,172 \\
\hline Netherlands & 5 & 29,124 & Taiwan & 5 & 2,007 \\
\hline Hong Kong & 13 & 28,828 & Greece & 4 & 1,817 \\
\hline S. Africa & 34 & 26,797 & Bulgaria & 53 & 865 \\
\hline Mexico & 13 & 14,261 & S. Korea & 4 & 773 \\
\hline Belgium & 17 & 11,027 & Pakistan & 1 & 196 \\
\hline Thailand & 63 & 10,617 & Finland & 1 & 75 \\
\hline
\end{tabular}

Source: EPRA Global REIT Survey, 2016 (as of 29.04.2017)

As shown on Table 3, to make comparison between the developed and emerging countries, Emlak Konut as an emerging country REIT is displaying 3,3 Million Euro market value, while the top developed country USA's REIT Simon Property Group is showing a 60,9 Million Euro market value. This gap among the market values, indicates the level of REIT performances between the two different markets.

Table 3: REITs in Various Countries

\begin{tabular}{|l|l|c|c|c|}
\hline Country & $\begin{array}{l}\text { Company } \\
\text { Name }\end{array}$ & $\begin{array}{c}\text { Total Market Value } \\
\text { (Million EUR) }\end{array}$ & $\begin{array}{c}\text { Annual Return } \\
\text { (EUR Based) }\end{array}$ & $\begin{array}{c}\text { Dividend } \\
\text { Yield }\end{array}$ \\
\hline USA & Simon Property Group & 60,966 & $24.66 \%$ & $2.82 \%$ \\
\hline Netherlands & Unibail-Rodamco & 24,244 & $5.59 \%$ & $3.94 \%$ \\
\hline Australia & Scentre Group & 18,965 & $39.12 \%$ & $3.94 \%$ \\
\hline Hong Kong & Link REIT & 14,608 & $29.14 \%$ & $3.56 \%$ \\
\hline France & Klépierre & 13,382 & $7.43 \%$ & $3.97 \%$ \\
\hline UK & Land Securities Group & 10,105 & $-13.01 \%$ & $3.20 \%$ \\
\hline Japan & Nippon Building Fund & 7,844 & $16.68 \%$ & $2.59 \%$ \\
\hline Canada & RioCan REIT & 6,150 & $13.00 \%$ & $4.87 \%$ \\
\hline Mexico & Fibra Uno Administracion & 6,016 & $-1.11 \%$ & $5.17 \%$ \\
\hline Singapore & CapitaLand Mall Trust & 5,159 & $12.67 \%$ & $5.29 \%$ \\
\hline
\end{tabular}




\begin{tabular}{|l|l|c|c|c|}
\hline S. Africa & Growthpoint Properties & 5,068 & $-4.87 \%$ & $4.96 \%$ \\
\hline Turkey & Emlak Konut & 3,372 & $5.53 \%$ & $3.30 \%$ \\
\hline Spain & Merlin Properties Socimi & 3,340 & $4.54 \%$ & $0.81 \%$ \\
\hline Belgium & Cofinimmo & 2,227 & $17.66 \%$ & $3.17 \%$ \\
\hline Germany & Alstria Office REIT AG & 1,899 & $2.98 \%$ & $4.02 \%$ \\
\hline Italy & Beni Stabili SpA & 1,316 & $-15.35 \%$ & $4.10 \%$ \\
\hline N. Zealand & Kiwi Property Group & 1,279 & $18.62 \%$ & $4.93 \%$ \\
\hline Malaysia & IGB REIT & 1,266 & $25.19 \%$ & $3.82 \%$ \\
\hline Ireland & Green REIT PIC & 1,004 & $-4.05 \%$ & $1.72 \%$ \\
\hline Greece & Grivalia Properties REIC & 711 & $-1.45 \%$ & $4.52 \%$ \\
\hline
\end{tabular}

Source: EPRA Global REIT Survey, 2016 (as of 29.05.2017)

\section{LITERATURE REVIEW}

In literature, many researchers have studied on REITs from different views and in different environments however risk/return analysis and examine financial performances are the much-examined area in REITs. One of the earliest study done by Chan et al. (1990) examined that there are three factors driven of REIT and general stock market: changes in the risk, term structure and unexpected inflation. They analyzed monthly returns on an equally weighted index of eighteen to twenty-three equity REITs that were traded on major stock exchanges over the 1973-1978 period. They employed a three-factor Arbitrage Pricing Model (APM) as well as Capital Asset Pricing Model (CAPM). They found that with CAPM there was an evidence of excess real estate returns, especially in the 1980s; but with APM, this evidence disappeared. Redman and Manakyan (1995) examined the risk-adjusted performance of REITs from 1986 to 1990 in relation to financial and property characteristics of their portfolios. The Sharpe measure of risk-adjusted rate of return was regressed against financial ratios (gross cash flow, leverage, asset size) and property investment ratios for a sample of equity and mortgage REITs. The result of their study is financial ratios, location of properties (more specifically, in the western United States) and types of real estate investment determine the risk-adjusted performance. Ziering et al. (1999) studied the relationship between real estate size and risk-return profile which is performance measurement. They found that real estate size is a powerful moderator of risk/return across the spectrum of size and that the largest category of real estate while providing investors with the highest average yield, also exhibits greatest volatility. Ambrose and Linneman (2001) stated that there is a positive relationship among REIT size, Revenue and Profit. The larger the size, the higher the rental income and profit margin therefore the better the yield. Chaudhry et al. (2004) and Hamelink and Hoesli (2004) stated that larger REITs are found to be more geographically diversified but less diversified across property types and this cause negative relationship among size and return. According to Ratcliffe and Dimowski (2007) there is a significant negative relationship between long term interest rates and returns, with a positive insignificant relationship with short term interest rates in Australian REITs. Yong et al. (2009) stated that there is an inverse relationship between returns and size implying that smaller yields tend to yield more return than the larger REITs. Alias and Tho (2011) examined the performance of six selected REITs in Malaysia (M-REITs) and the United Kingdom (UK-REITs). Researchers findings and analysis showed that the total revenue was the main factor affecting the performance for both the largest M-REITs and UK-REITs. Furthermore, they also demonstrated that for every billion increases in market capitalization, the profit margins generated by the REITs will raise by approximately $9 \%$. Brounen and Sjoerd (2012) attributed REIT stock outperformance in Europe to size, specialization and geographic focus. Gabriel et al. (2015) clustered American (USA-REITs) and Brazilian (BR-REITs) Real Estate Investment Trusts based on their risk-adjusted measures of performance from January/2003 to August/2013, as well as before, during and after the financial crisis of 2008 by using factor and cluster. They found out that BR-REITs achieved a better performance before and during the crisis, but an inferior performance after the crisis. USA-REITs presented a more aggressive strategy after the crisis, whilst BR-REITs presented a more conservative strategy during the same period.

Even though many studies about REITs were undertaken in many countries, however there are quite limited literature devotes from Borsa Istanbul perspective. For instance, Kıyılar and Hepşen (2010) carried out a study on performance appraisal of real estate investment trusts traded on Borsa Istanbul. The sample for the study was composed of eight REITs covering the period between January 2000 and December 2008. Reasearchers employed the Sharpe Index and the Jensen Index to measure the performance of each REIT relative to the market portfolio. The results of the study indicated that Pera REIT performed better than the other REIT stocks for both Sharpe and Jensen Indices over the period. Önder et al. (2014) evaluated the financial 
performance model of Turkish Real Estate Investment Trusts (REITs) during 2012-2013 period using Analytical Network Process (ANP) and Technique for Order Preference by Similarity to Ideal Solution (TOPSIS) methodologies. Their model applied to a case study for the financial performance evaluation of 24 REITs. They found that Return on Equity, Return on Asset, Net Profit Margin and Long-Term Assets/Total Assets are the four most important financial ratios for the performance of the REITs. A recent study was carried out by islamoglu et al. (2015) assessing the financial performance of REITs by means of liquidity, profitability, turnover and capital structure ratios in Turkey using Entropy Based TOPSIS method. The results of the method showed that the weighting of liquidity ratios was found to be high as İdealist, Vakif, Alarko and Atakule had by far the highest liquidity ratios among the REITs. Due to the structure of the industry, as real estate projects are liquidated following their completion, the current assets of the firms notably increase. Among the REITs, the asset and capital structure ratios had closer distance values compared to profitability and turnover ratios, especially the values of capital to asset ratio had the closest distance values. Therefore, the weighting of asset and capital structure criteria were found to be the lowest according to the results of the Entropy Method.

\section{METHODOLOGY AND FINDINGS}

The main provision of making the analyses healthfully depends on the fact that the real estate investment trusts in the sector are correctly grouped by their scales. In this sense, each of the variables in the data set was firstly standardized by using median instead of mean. Then, the scoring was performed according to defined coefficients. After that normality test of the obtained scores was performed, the area of each score under standard normal distribution curve was calculated and the scores were moved to the 0-100 range. Finally, scores were clustered by using k-means algorithm. It was found appropriate to conduct a survey on the internet to direct this study in the light of more objective and concrete information. Accordingly, a survey study was conducted by using an online survey tool called Survey Monkey to 990 people that consist of both foreign and domestic investors, to get opinions about REIT stock market in Turkey, to learn priority preferences, and to determine the weights in scoring work according to these priorities. According to the survey results, in the present study 31 REITs which were traded on Istanbul Stock Exchange were firstly subjected to clustering by considering the median values of the last 5 years according to the following criteria, and then the related variables were scored based on the effect coefficients shown in Table 4. After compatibility of these scores for normal distribution was tested, the scores were moved to the 0-100 range and ordered. Finally, the firms were gathered in 5 groups according to their performances by using K-Means Algorithm.

The following standardization method was used for each variable:

Standardized Value $=\frac{x-\operatorname{median}(x)}{\sqrt{\sum_{i=1}^{n}\left(x_{i}-\operatorname{median}(x)\right)^{2}}}$

Table 4: Selected Variables

\begin{tabular}{|c|l|}
\hline Effect Coefficient & Variables \\
\hline 0.2500 & Asset Growth \\
\hline 0.2500 & Return on Assets \\
\hline-0.2500 & Net Debt/EBITDA \\
\hline 0.5000 & Gross Profit Growth \\
\hline 0.5000 & Dividend Yield \\
\hline 0.2500 & Share of Real Estate Investments in Portfolio \\
\hline 0.2500 & Share of Affiliates in Portfolio \\
\hline-0.2500 & Share of Money and Capital Market Instruments in Portfolio \\
\hline 0.5000 & Free Float Market Value's Exceeding 100 Million TL \\
\hline 0.5000 & Equity Capital Size's Exceeding 500 Million TL \\
\hline 0.2500 & Total Asset Size's Exceeding 1 Billion TL \\
\hline 0.2500 & Total Sales' Exceeding 100 Million TL \\
\hline
\end{tabular}




\begin{tabular}{|l|l|}
\hline 0.2500 & Whether or not REIT is in BIST 100 Index \\
\hline 0.2500 & Whether or not REIT is in BIST Dividend Index \\
\hline 0.2500 & Whether or not REIT is in BIST Corporate Governance Index \\
\hline
\end{tabular}

The standardized values were weighted with the above effect coefficients and scores were obtained. Later, it was determined that the obtained scores complied with normal distribution by using Shapiro-Wilk Normality Test. R Studio was used for ShapiroWilk Normality Test. As seen in Table 5, the "Data is compatible with Normal Distribution" null hypothesis could not be rejected because the $P$ value was greater than the significance value determined as $0.05(0.5492>0.05)$, and it can be asserted that the obtained scores complied with normal distribution with a confidence level of 0.95 .

Table 5: Shapiro-Wilk Normality Test Results

\begin{tabular}{|l|l|}
\hline $\mathbf{W}$ & 0.97108 \\
\hline $\mathbf{P}$ Value & 0.54920 \\
\hline
\end{tabular}

It's now possible to move the scores between 0-100 since they met normal distribution. Therefore, it's required to calculate the area of each score under the standard normal distribution curve. In order to calculate the area, p-norm function on $\mathrm{R}$ Studio was used and all scores were moved to 0-1 range. Then, all scores were multiplied by 100 and moved to 0-100 range. Lastly, they were collected under 5 groups as "Very good, Good, Not Bad, Bad and Very Bad" by using k-means algorithm. Clustering were made on R Studio. K-means algorithm is one of the simplest algorithms that solve the well-known clustering problem. The procedure follows a simple and easy way to classify a given data set by using a certain number of clusters. The main idea is to define $k$ centroids, one for each cluster. These centroids should be placed in a cunning way since different locations cause different results. So, the better choice is to place them as much as possible far away from each other. The next step is to take each point belonging to a given data set and associate it to the nearest centroid (Liberty, 2012). Accordingly, within the scope of the data of 2011-2015 obtained from Istanbul Stock Exchange, Capital Markets Board and Public Disclosure Platform, 31 REITs were grouped as shown in Table 6.

Table 6: Results of Analysis

\begin{tabular}{|l|c|c|c|}
\hline Company Name & Score & Rank & Cluster \\
\hline IS REIT & 100,0 & 1 & Very Good \\
\hline YENI GIMAT REIT & 100,0 & 2 & Very Good \\
\hline TORUNLAR REIT & 99,9 & 3 & Very Good \\
\hline PANORA REIT & 99,8 & 4 & Very Good \\
\hline AKMERKEZ REIT & 99,8 & 5 & Very Good \\
\hline SAF REIT & 99,7 & 6 & Very Good \\
\hline AKIS REIT & 99,6 & 7 & Very Good \\
\hline EMLAK KONUT REIT & 99,0 & 8 & Very Good \\
\hline VAKIF REIT & 97,5 & 9 & Very Good \\
\hline SINPAS REIT & 93,2 & 10 & Good \\
\hline HALK REIT & 91,9 & 11 & Good \\
\hline AKFEN REIT & 91,6 & 12 & Good \\
\hline OZAK REIT & 89,0 & 13 & Good \\
\hline DOGUS REIT & 88,9 & 14 & Good \\
\hline ALARKO REIT & 88,8 & 15 & Good \\
\hline NUROL REIT & 84,8 & 16 & Good \\
\hline YESIL REIT & 73,9 & 17 & Not Bad \\
\hline
\end{tabular}




\begin{tabular}{|l|c|c|c|}
\hline SERVET REIT & 73,6 & 18 & Not Bad \\
\hline AVRASYA REIT & 71,4 & 19 & Not Bad \\
\hline OZDERICI REIT & 66,7 & 20 & Not Bad \\
\hline YAPI KREDI KORAY REIT & 63,4 & 21 & Not Bad \\
\hline REYSAS REIT & 61,7 & 22 & Not Bad \\
\hline PERA REIT & 53,2 & 23 & Not Bad \\
\hline ATAKULE REIT & 40,5 & 24 & Bad \\
\hline TSKB REIT & 39,3 & 25 & Bad \\
\hline IDEALIST REIT & 34,9 & 26 & Bad \\
\hline MARTI REIT & 22,1 & 27 & Bad \\
\hline KILER REIT & 21,7 & 28 & Bad \\
\hline KORFEZ REIT & 16,1 & 29 & Very Bad \\
\hline DENIZ REIT & 2,9 & 30 & Very Bad \\
\hline ATA REIT & 1,1 & 31 & Very Bad \\
\hline
\end{tabular}

\section{CONCLUSION}

As in many developed and developing countries, REITs, which are an important capital market instrument in Turkey as well, have showed a rapid development all around the world especially in 1990s. REITs are capital market institutions which can invest the resources, they gather from their investors in return for certificates of stock, on real estates, real estate-based capital market instruments, and real estate projects and are established based on principle of distributing their earnings to their investors as a dividend. In general, investors can participate in real estates in REIT's portfolio in small rates by taking the shares of REITs traded in stock markets. Thus, investors can both benefit from the appreciation of assets in the REIT's portfolio and convert the share certificates into cash in the stock exchange at any time. On the other hand, real estate investment trusts enable small deposits to create resources for large-scale real estate projects, leading to the formation of a healthy urbanization by avoiding unplanned urbanization. From these perspectives, it is known that Real Estate Investment Trusts undertake important roles in gaining the idle resources into economy due to unrecorded real estate investments. Real estate investments have become excessively preferred investment instruments in developing economies such as Turkey because of having lower risk than other investment instruments and offering high yield opportunities to their investors in the long run. However, when examining the real estate sector in Turkey, it is observed that housing financing or, in a broader sense, a very small part of real estate financing is realized through capital markets. There are numerous causes behind why capital markets are not sufficiently integrated into the real estate market. One of these causes is the lack of institutionalization. However, even though there has been issue of many different financing instruments based on real estate through capital markets except for housing in recent years, the best example of the institutionalized real estate financing is REITs. It is seen that REITs, which are among the most important investment instruments based on real estate, remain mostly incapable in terms of investor satisfaction because they are traded at a discount when their share performances in Turkey comparing with their counterparts abroad. The main purpose of this study is to investigate the underlying causes of this situation creating dissatisfaction in terms of both domestic and foreign investors. As we have tried to explain in the previous sections of the study, the continuity and value creation of the real estate sector are very important both for the investor and, perhaps more importantly, for the contribution to the country's economy. When examining the examples in the world, the main reasons of why the REITs, which are a highly efficient and preferred financial instrument, have not reached the levels desired over the past 20 years since 1995 are as follows;

- low transaction volume on the stock market,

- no obligation of disclosing the net asset value,

- insufficient investor relations,

- $\quad$ loss of trust during public offering 
- $\quad$ unhealthy and insecure sectoral data,

- $\quad$ current dividend policy

- $\quad$ REITs with very different portfolio sizes and diversities,

- confusions on the regulations side

These reasons affect values of REIT shares with various weights and consequently cause REITs to be traded below net asset values. Since the Capital Markets Board has ruled out the obligation to disclose Net Asset Value (NAV) data of REITs starting from 2011, it's now the case that following of this important indicator has been left to the initiative of analysts or to companies' guidance. This made comparison and following of company performances difficult and thus created some question marks about transparency. Since there is no regulation made about dividend distribution by the CMB until today, REITs make profit distribution decisions at the rates determined by the general assemblies by the end of the year and cannot display a sustainable profit share distribution policy for the investor. Thus, this situation is assessed as a negative matter in terms of REIT investor.

On the other hand, especially in most of the REITs operating in Turkey, there are also cases of experiencing problems in sharing data of the company performance with domestic and foreign investors because of unauthorized personnel in the investor relations departments as well as the inadequacy of answering the questions during the meetings held with investors. It is also a fact that the disclosed data related to the sector are inadequate compared to the data disclosed in foreign countries, their continuity is problematic and their reliability is debatable. It's an important matter to consolidate and support all the sectoral data with the data provided by specialized consultancy firms to share more healthy and common data during investor presentations. In addition, the fact that REITs publish their own data regularly on their web sites and enable analysts to have easy access to information will also give the sector a more transparent and reliable identity in the presence of investors. In brief; analyses conducted by the researchers show that REITs traded on the stock exchange are divided into two subgroups depending on their financial data. It will be important the REITs, in the sub-group especially in terms of the score distribution, to diversify their portfolio by extending their asset investments, to stabilize dividend payments and to take steps on institutionalization so that they are equivalent to REITs in the super-group. Results of this study are hoped to help the investors and portfolio managers to deepen their understanding of the dependence factors that might influence the performance of REITs in Istanbul Stock Exchange.

\section{REFERENCES}

Alias, A. \& Tho, S. 2011, "Performance Analysis of REITs: Comparison Between M-REITs and UK-REITs", Journal of Surveying, Construction and Property, vol.2, special issue, pp.38-61.

Ambrose, B.W. \& Linneman, P.D. 2001, "REIT Organizational Structure and Operating Characteristics”, Journal of Real Estate Research, vol.21, no.3, pp.141-162.

Association of Real Estate and Real Estate Investment Companies, 2016, REIT Guide (Available at www.gyoder.org.tr).

Basse, T. \& Friedrich, M. 2009, "REITs and the Financial Crisis: Empirical Evidence from the U.S.", International Journal of Business and Management, vol.14, no.11, pp.1-10.

Capital Markets Board (CMB), 2016, Monthly Statistical Bulletin (Available at www.spk.gov.tr).

Chan, K.C. et al. 1990, "Risk and Return on Real Estate: Evidence from Equity REITs", The Journal of American Real Estate and Urban Economics Association, vol.18, no.4, pp.431-452.

Chaudhry, M.K. et al., 2004. "REITs and Idiosyncratic Risk", Journal of Real Estate Research, vol.26, no.2, pp.207-222.

Chiang, Y.H., et. al. 2008, "Time-Varying Performance of Four Asia-Pacific REITs", Journal of Property Investment and Finance, vol.26, no.3, pp.210-231.

Edo, L.. 2012, “K-means Clustering, Algorithms in Data Mining", [Online] http://www.cs.yale.edu/homes/el327/ datamining2012aFiles/11_k_means_clustering.pdf

European Public Real Estate Association (EPRA), 2016, Global REIT Survey, (Available at www.epra.org). 
Gabriel F.S. et al. 2015, "Clustering Real Estate Investment Trusts: Brazil versus United States”, Journal of Management Research, vol.7, no.4, pp. 166-190

Hamelink, F. \& Hoesli, M. 2004, "What Factors Determine International Real Estate Security Returns", Real Estate Economics, vol.32, no.3, pp.437-462.

İslamoğlu M. et al. 2015, "An Evaluation of the Financial Performance of REITs in Borsa Istanbul: A Case Study Using the Entropy-Based TOPSIS Method", International Journal of Financial Research, vol.6, no.2, pp.124-138.

Kıyılar, M. \& Hepşen, A. 2010, "Performance Appraisal of Real Estate Investment Trusts (REITs): A Practice in Istanbul Stock Exchange", Yönetim Journal, vol.21, no.65, pp.11-23.

Önder E. et al. 2014, "REITs in Turkey Fundamentals vs Market", International Journal of Latest Trends in Finance and Economic Sciences, vol.4, no.1, pp.1-15.

Ratcliffe, C. \& Dimowski, B. 2007, "The Responsiveness of LPT Returns and Their Attributes", Pacific Rim Property Research Journal, vol.13, no.3, pp.280-297.

Redman, A.L. \& Manakyan, H. 1995, “A Multivariate Analysis of REIT Performance by Financial and Real Asset Portfolio Characteristics", Journal of Real Estate Finance and Economics, vol.10, pp.169-175.

Shapiro-Wilk Normality Test, R Documentation, [Online] https://stat.ethz.ch/R-manual/R-devel/library/stats/html/shapiro.test.html

The Normal Distribution, R Documentation, [Online] https://stat.ethz.ch/R-manual/R-devel/library/stats/html/Normal.html

Titman, S. \& Warga, A. 1986, "Risk and the Performance of the Real Estate Investment Trusts: A Multiple Index Approach", Journal of the American Real Estate and Urban Economics Association, vol.14, no.3, pp.414-431.

Yong, J., et al. 2009, "AREIT Returns from 1990-2008: A Multi-Factor Approach", Conference Proceeding, Paper presented at the 18th World IMACS/MODSIM Congress, Cairns, Australia.

Ziering, B. et al. 1999, "REIT Correlations with Capital Market Indexes: Separating Signal from Noise”, Real Estate Finance, vol.15, no.4, pp.61-67. 